\title{
PENGGUNAAN RUANG BAWAH TANAH UNTUK BANGUNAN GEDUNG DITINJAU DARI PERATURAN PERUNDANG-UNDANGAN TERKAIT YANG BERLAKU
}

\author{
THE USE OF UNDERGROUND SPACE FOR BUILDING BASED ON RELATED \\ APPLICABLE REGULATIONS
}

\author{
Siti Sarah Afifah", Nia Kurniati**, Yusuf Saepul Zamil ${ }^{* * *}$
}

\begin{abstract}
ABSTRAK
B ertambahnya jumlah manusia yang membutuhkan tanah luasan/areal lahan (tanah) erbatas, menyebabkan maraknya penggunaan ruang bawah tanah di Indonesia, khususnya di kota-kota besar seperti Kota Bandung, Jakarta, dan Makassar. Hal tersebut didukung pula dengan perkembangan teknologi yang pesat saat ini. Permasalahan muncul ketika penggunaan tanah dilakukan secara 3 (tiga) dimensi sedangkan dasar obyek pendaftaran tanah merupakan bagian-bagian permukaan bumi tertentu yang berbatas dan berdimensi 2 (dua). Berdasarkan permasalahan tersebut, maka dilakukan penelitian dengan tujuan untuk menemukan legalitas bangunan gedung yang dibangun di ruang bawah tanah, dan menemukan akibat hukum penggunaan ruang di bawah tanah untuk bangunan gedung ditinjau dari peraturan perundang-undangan terkait yang berlaku.

Metode penelitian yang digunakan adalah deskriptif analitis yaitu melalui penelitian ini, diharapkan dapat diperoleh gambaran secara komprehensif mengenai penggunaan ruang di bawah tanah untuk bangunan gedung. Metode pendekatan yang digunakan dalam penelitian ini adalah yuridis normatif, yaitu pengumpulan data yang diperoleh dari studi kepustakaan dan studi peraturan perundang-undangan yang berkaitan dengan penggunaan ruang di bawah tanah untuk bangunan gedung. Penggunaan tanah dengan 3 (tiga) dimensi yang berarti tidak hanya menyangkut ukuran panjang dan lebar tanah saja, melainkan juga menyangkut ukuran tinggi/kedalaman tanah. Sehingga dalam penggunaan ruang bawah tanah harus memperhatikan aspek-aspek hukum lainnya yang terkait seperti aspek hak atas tanah, penataan ruang, dan perizinan, agar ruang bawah tanah dapat dipergunakan secara legal, dan optimal sesuai dengan tujuan, dengan tetap menjaga aspek penataan ruang dan lingkungan.
\end{abstract}

Kata kunci: bangunan gedung; izin mendirikan bangunan; penggunaan ruang bawah tanah.

\section{ABSTRACT}

$T^{i}$ The increasing number of people who need land but the area / land area (land) is limited, causing widespread use of underground space in Indonesia, especially in big cities such as the City of

\footnotetext{
Mahasiswa Fakultas Hukum Universitas Padjadjaran, Jalan Dipati Ukur No. 35 Bandung, email: sitisarahafifah@ gmail.com.

** Dosen Fakultas Hukum Universitas Padjadjaran, Jalan Dipati Ukur No. 35 Bandung, email: nia_widiawan@yahoo. com.

*** Dosen Fakultas Hukum Universitas Padjadjaran, Jalan Dipati Ukur No. 35 Bandung, email: yusuf.zamil@gmail. com.
} 
Bandung, Jakarta and Makassar. This is also supported by the rapid development of technology at this time. Problems arise when the use of land is done in 3 (three) dimensional not only in 2 (two) dimensional, while the base of the object of registration of land are limited and two-dimensional parts only. Based on the problem stated, the aim of this research are to find the legality of the building which built underground and to find the legal consequences use of underground spaces for building based on related applicable regulations.

The research method used is analytical descriptive, it is expected to get a comprehensive picture about the use of underground space for buildings. The approach method used in this research is normative juridical, by collecting data that obtained from literature study and study of legislation relating to the use of underground for building. The use of land with 3 (three) dimensions which means not only concerning the size of the length and width of the land, but also concerning the size of the height / depth of the soil, ie in this case using the basement for buildings. So, the use of space underground should pay attention to other related legal aspects such as Aspects of land rights, spatial arrangement, and licensing, so that the basement can be used legally, and optimally in accordance with the objectives, while maintaining the aspect of spatial and environmental arrangement.

Keyword: buildings; building permit; the use of underground space.

\section{PENDAHULUAN}

$\mathrm{D}$ i era perkembangan teknologi yang pesat saat ini, pendirian sebuah bangunan tidak hanya terbatas pada penggunaan tanah secara 2 (dua) dimensi saja, namun sudah secara 3 (tiga) dimensi, yaitu dengan menggunakan ruang di bawah tanah.

Penggunaan ruang bawah tanah sudah sering terjadi di Indonesia, terutama di kota besar seperti Kota Bandung. Sudah banyak bangunan yang dibangun di bawah tanah yang kemudian dimanfaatkan sebagai lahan parkir (basement), ataupun sebagai tempat tinggal yang seringkali digunakan untuk tempat penyimpanan barang (gudang). Hal tersebut terjadi tidak lain disebabkan oleh adanya keterbatasan jumlah lahan (tanah), sedangkan jumlah manusia yang membutuhkan tanah semakin bertambah.

Penggunaan dan pemanfaatan tanah tidak terlepas dari status hak atas tanah yang melekat pada tanah yang digunakan. Berdasarkan Pasal 4 Ayat (1) dan (2) UndangUndang Nomor 5 Tahun 1960 Tentang
Peraturan Dasar Pokok-Pokok Agraria (yang selanjutnya disebut UUPA) ditentukan bahwa adanya macam-macam hak atas permukaan bumi yang disebut tanah, yang melekat wewenang atas hak-hak atas tanah tersebut bagi para pemegang haknya untuk mempergunakan tanah yang bersangkutan, demikian tubuh bumi dan air serta ruang yang ada di atasnya sekedar diperlukan untuk kepentingan yang langsung berhubungan dengan penggunaan tanah dalam batasbatas menurut UUPA dan peraturanperaturan hukum yang lebih tinggi. Untuk memberikan kepastian hukum, tanah tersebut wajib didaftarkan. Pendaftaran tanah menjadi kewajiban bagi pemerintah maupun pemegang hak atas tanah, sebagaimana ketentuan dalam Pasal 19 UUPA.

Permasalahan muncul ketika penggunaan tanah dilakukan secara 3 (tiga) dimensi tidak hanya secara 2 (dua) dimensi, sedangkan dasar obyek pendaftaran tanah merupakan bagian-bagian permukaan bumi tertentu yang berbatas dan berdimensi dua. Dalam hal pendaftaran tanah, data fisik tanah 
yang nantinya akan dimuat dalam sertipikat hak atas tanah sebagaimana ketentuan dalam Pasal 32 Ayat (1) Peraturan Pemerintah Nomor 24 Tahun 1997 tentang Pendaftaran Tanah (selanjutnya disebut PP Pendaftaran Tanah) yang haknya didaftarkan hanya mengenai letak, batas, dan luas bidang tanah yaitu perhitungan panjang dikali lebar luas bidang tanah, termasuk keterangan mengenai adanya bangunan atau bagian bangunan di atasnya. Dengan begitu menandakan bahwa sertipikat hak atas tanah yang memuat data fisik hanya mendukung keberadaan penggunaan tanah secara 2 (dua) dimensi saja, tidak dengan penggunaan tanah secara 3 (tiga) dimensi. Persoalan lain muncul ketika legalitas bangunan yang berada di bawah tanah dipertanyakan.

Kemudian, pemberlakuan asas pemisahan horizontal di dalam hukum pertanahan di Indonesia memberikan pemisahan antara kepemilikan tanah dengan apa yang melekat di bawahnya dan berada di bawahnya, hanya yang langsung berhubungan dengan penggunaan tanah saja yang dapat dimanfaatkan. Hal ini membatas kewenangan pemilik hak atas tanah dalam memanfaatkan tanah yang dimilikinya, karena pemanfaatan apa yang terkandung di dalam tanah dan yang melekat di atasnya harus dapat dibuktikan bahwa memang dan hanya yang berkaitan dengan penggunaan tanah tersebut. ${ }^{1}$

Dalam menggunakan tanah secara 3(tiga) dimensi, salah satunya dengan mendirikan bangunan gedung di ruang bawah tanah, tentu tidak dapat dilakukan begitu saja.
Perlu ada izin, yaitu Izin Pemanfaatan Ruang sebagai sarana pengendalian penggunaan ruang bawah tanah yang harus dipenuhi, dan Izin Mendirikan Bangunan ketika akan membangun suatu bangunan di ruang bawah tanah, serta penyesuaian dengan hak atas tanah yang melekat pada permukaan tanah. Permukaan tanah yang dimanfaatkan harus sesuai dengan peruntukan haknya. Begitupula ketika memanfaatkan ruang bawah tanah.

Semakin maraknya penggunaan ruang bawah tanah seperti yang terjadi Kota Bandung, maka dirasa perlu adanya kepastian hukum mengenai penggunaan ruang bawah tanah yaitu berupa adanya pemberian hak guna ruang bawah tanah. Persoalan hukum yang utama adalah masalah hukum tanah yang hingga saat ini belum terdapat suatu aturan yang mengatur tentang hak guna ruang bawah tanah, walaupun saat ini Dewan Perwakilan Rakyat (DPR) sedang mempersiapkan Rancangan Undang-Undang (RUU) Pertanahan yang akan mengatur tentang lembaga tersebut. Selain itu, persoalan teknis yang muncul adalah terkait kenyamanan dari segi teknis bangunan yang berada di ruang bawah tanah.

Berdasarkan uraian di atas, maka adanya penggunaan ruang bawah tanah dapat menimbulkan pertanyaan yang menjadi identifikasi masalah dalam penelitian ini, yaitu bagaimanakah legalitas bangunan gedung yang berada di ruang bawah tanah dan bagaimanakah akibat hukum atas penggunaan ruang di bawah tanah untuk bangunan gedung ditinjau dari peraturan perundang-undangan terkait yang berlaku?

\footnotetext{
${ }^{1}$ Ires Amanda Putri, Jurnal Singkat: Asas Pemisahan Horizontal dalam Pemanfaatan Ruang Bawah Tanah Berdasarkan Hukum Pertanahan Indonesia (Tinjauan Yuridis terhadap Putusan Mahkamah Agung Nomor 740 K/Pdt/2009, Putusan Mahkamah Agung Nomor 292 PK/Pdt/2009, Putusan Mahkamah Agung Nomor 2030 K/Pdt/2003), Depok: Fakultas Hukum Universitas Indonesia, 2013, hlm. 5. Diunduh pada http://www.lib.ui.ac.id/naskahringkas/2015-08/ S44794-ires\%20amanda\%20putri Rabu, 3 Mei 2017 Pukul 01.48 WIB.
} 
Penggunaan ruang bawah tanah akan memberikan dampak dalam bidang hukum karena peraturan-peraturan yang sudah ada dirasa tidak mendukung secara menyeluruh dan selaras dalam mengatur penggunaan ruang bawah tanah khususnya untuk bangunan gedung.

Metode penelitian yang digunakan adalah deskriptif analitis yaitu melalui penelitian ini, diharapkan dapat diperoleh gambaran secara komprehensif mengenai penggunaan ruang di bawah tanah untuk bangunan gedung. Metode pendekatan yang digunakan dalam penelitian ini adalah yuridis normatif, yaitu pengumpulan data yang diperoleh dari studi kepustakaan dan studi peraturan perundang-undangan yang berkaitan dengan penggunaan ruang di bawah tanah untuk bangunan gedung.

\section{PEMBAHASAN}

Legalitas Bangunan Gedung yang Berada di Ruang Bawah Tanah Ditinjau dari Peraturan Perundang-Undangan Terkait yang Berlaku

Jum umlah penduduk yang semakin meningkat, namun keberadaan lahan/tanah yang tidak bertambah (tetap) menyebabkan meluasnya penggunaan dan pemanfaatan tanah yang saat ini tidak hanya terbatas pada permukaan tanah saja, melainkan juga ruang bawah tanah dan ruang atas tanah (ruang udara). Agar pemanfaatan ruang dilakukan sesuai dengan rencana tata ruang, diperlukan adanya suatu pengendalian pemanfaatan ruang yang dilakukan melalui penetapan peraturan zonasi, perizinan, pemberian insentif dan disinsentif serta pengenaan sanksi. ${ }^{2}$

Bangunan-bangunan gedung saat ini tidak hanya didirikan di atas permukaan tanah, namun juga sudah banyak yang berada di ruang bawah tanah, atau bahkan melayang di ruang udara sebagai bangunan penghubung antar bangunan gedung. Dalam Pasal 1 butir 1 UUPR ditegaskan bahwa:

"Ruang adalah wadah yang meliputi: ruang darat, laut, dan udara, termasuk ruang di dalam bumi sebagai satu kesatuan wilayah, tempat manusia dan makhluk lain hidup, melakukan kegiatan, dan memelihara kelangsungan hidupnya".

Hal ini menunjukkan bahwa ruang tidak hanya ruang darat, melainkan juga ruang laut, udara, dan ruang di dalam bumi/ruang bawah tanah.

Pasal 4 Ayat (1) UUPA, yang menyatakan:

"Atas dasar hak menguasai dari Negara sebagai yang dimaksud dalam Pasal 2 ditentukan adanya macam-macam hak atas permukaan bumi, yang disebut tanah, yang dapat diberikan kepada dan dipunyai oleh orang-orang, baik sendiri maupun bersama-sama dengan orangorang lain serta badan-badan hukum".

Hak atas permukaan bumi yang tercantum dalam pasal tersebut juga disebut hak atas tanah. Hak atas tanah sebagai suatu hubungan hukum didefinisikan sebagai "hak atas permukaan bumi yang memberi wewenang kepada pemegangnya untuk menggunakan tanah yang bersangkutan, beserta tubuh bumi dan air serta ruang udara di atasnya, sekadar diperlukan untuk kepentingan yang langsung berhubungan dengan penggunaan tanah itu, dalam batasbatas menurut UUPA dan peraturan hukum lain yang lebih tinggi" (Pasal 4 Ayat 2). Hal itu mengandung arti bahwa hak atas tanah

\footnotetext{
2 Pasal 35 Undang-Undang Nomor 26 Tahun 2007 tentang Penataan Ruang beserta penjelasannya.
} 
itu disamping memberikan wewenang juga membebankan kewajiban kepada pemegang haknya. ${ }^{3}$ Kewajiban tersebut antara lain: ${ }^{4}$

a. Adanya ketentuan yang terdapat dalam Pasal 6 UUPA, bahwa semua hak atas tanah mempunyai fungsi sosial;

b. Adanya ketentuan Pasal 15 UUPA, yaitu kewajiban memelihara tanah dan mencegah kerusakannya;

c. Khusus untuk tanah pertanian adanya ketentuan Pasal 10 UUPA yang memuat asas bahwa tanah pertanian wajib dikerjakan sendiri oleh pemiliknya secara aktif.

Kewenangan mempergunakan tanah dalam arti permukaan bumi tersebut, secara wajar diperluas hingga meliputi sebagian tubuh bumi yang ada di bawahnya dan sebagian ruang yang ada di atasnya, karena tidak mungkin untuk keperluan apa pun yang ada di gunakan hanya tanahnya saja yang berupa permukaan bumi itu, ${ }^{5}$ yang diperluas hingga meliputi sebagian tubuh bumi, sebagian ruang dan air tersebut adalah penggunaannya, bukan pemilikannya. ${ }^{6}$ Hak atas tanah tidak meliputi pemilikan kekayaan alam yang ada dalam tubuh bumi di bawahnya (Pasal 8). Juga tidak dengan sendirinya meliputi bangunan dan tanaman yang ada di atas tanah yang dihaki, karena berlakunya asas pemisahan horizontal dalam hukum kita. Tetapi sesuai dengan hukumnya dalam hukum adat, bangunan yang dibangun dan tanaman yang ditanam adalah milik pihak yang membangun dan menanamnya. ${ }^{7}$
Ketentuan-ketentuan tersebut telah memberikan hak, yaitu hak atas tanah kepada para pemegang hak atas tanah, individu maupun badan hukum, untuk menggunakan dan memanfaatkan tanah baik permukaan tanah, ruang bawah tanah, dan ruang udara, sekedar diperlukan untuk kepentingan yang langsung berhubungan dengan penggunaan tanah itu dalam batas-batas menurut UUPA dan peraturan lain yang lebih tinggi. Didukung dengan adanya ketentuan dalam Pasal 32 Ayat (2) UUPR yang menyebutkan bahwa

"Pemanfaatan ruang sebagaimana dimaksud pada ayat (1) dapat dilaksanakan dengan pemanfaatan ruang, baik pemanfaatan ruang secara vertikal maupun pemanfaatan ruang di dalam bumi."

Dalam penggunaan ruang bawah tanah, yang harus diperhatikan salah satunya ialah hak atas tanah yang melekat pada bidang tanah tersebut. Hak atas tanah dapat dibuktikan dengan sertipikat hak atas tanah, yang memuat data fisik dan data yuridis di dalamnya, sepanjang data fisik dan data yuridis tersebut sesuai dengan data yang ada dalam surat ukur dan buku tanah hak yang bersangkutan. Namun, sebagaimana ketentuan dalam Pasal 1 angka 6 PP Pendaftaran Tanah, Penulis berpendapat bahwa sertipikat hak atas tanah belum mendukung penggunaan ruang bawah tanah, karena dalam data fisik hanya mengenai letak, batas, dan luas bidang tanah yaitu perhitungan panjang dikali lebar luas bidang tanah, termasuk keterangan mengenai

\footnotetext{
${ }^{3}$ Maria S.W. Sumardjono, Tanah dalam Perspektif Hak Ekonomi, Sosial, dan Budaya, Penerbit Buku Kompas, Jakarta, 2008, hlm. 128.

${ }^{4}$ Achmad Chulaemi, dikutip dari Bernhard Limbong, Politik Pertanahan, Margaretha Pustaka, Jakarta, 2014, hlm 61-62.

5 Boedi Harsono, Hukum Agraria Indonesia: Sejarah Pembentukan Undang-Undang Pokok Agraria, Isi dan Pelaksanaannya, DJambatan, Jakarta, 2008, hlm 293.

${ }^{6}$ Ibid.

7 Ibid., hlm. 294.
} 
adanya bangunan atau bagian bangunan di atasnya. Dengan begitu menandakan bahwa sertipikat hak atas tanah yang memuat data fisik hanya mendukung keberadaan penggunaan tanah secara 2 (dua) dimensi saja, tidak dengan penggunaan tanah secara 3 (tiga) dimensi. Hak atas tanah sebagaimana yang tercantum dalam sertipikat atas tanah yang sudah didaftarkan tidak memberikan kepastian hukum terhadap penggunaan hak atas tanahnya secara 3 (tiga) dimensi karena pengukuran tinggi (kedalaman) tanah yang digunakan tidak merupakan bagian dari data fisik yang dimuat dalam sertipikat.

Pemegang hak atas tanah boleh menggunakannya untuk keperluan pribadinya, misalnya untuk keperluan seharihari bagi kegiatan rumah tangga danusahanya, dalam batas-batas kewajaran. ${ }^{8}$ Menurut Bapak Syaiful Iman $^{9}$ penggunaan ruang bawah tanah yang mana pada permukaan tanahnya berstatus hak milik bagi individu tertentu diperbolehkan, sepanjang penggunaan tersebut sesuai dengan peruntukan hak atas tanahnya, yang berarti hanya sebatas untuk menunjang pemanfaatan hak milik tersebut. Misalnya tanah yang digunakan untuk bangunan rumah tinggal, penggunaan ruang bawah tanah diperbolehkan untuk dibangun basement yang kemudian dimanfaatkan untuk lahan parkir atau gudang tempat penyimpanan barang. Jika penggunaan bangunan untuk basement tidak lebih dari 2 lapis, proses perizinan dilakukan seperti biasa. Namun jika lebih dari 2 lapis harus melalui tim ahli bangunan gedung. ${ }^{10}$

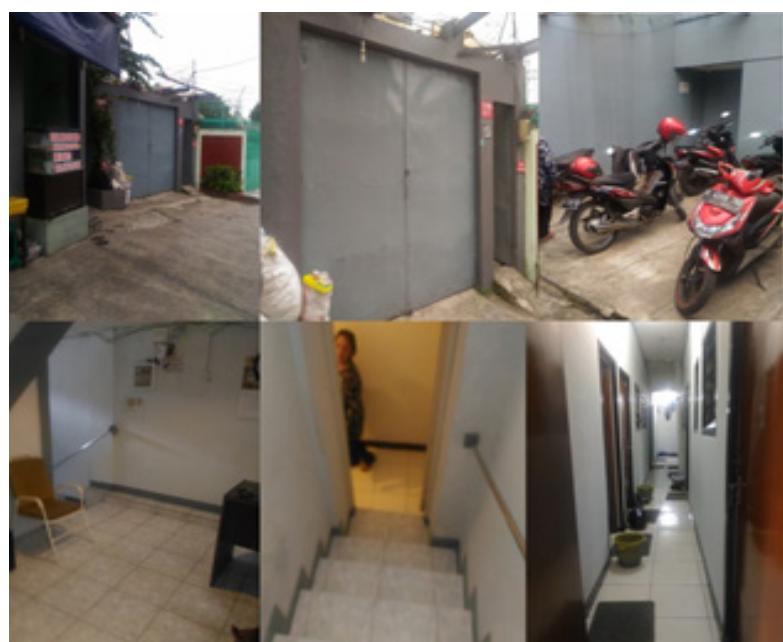

Gambar 1.1 Bangunan Gedung di Jl. Cipaku Permai yang Berada di Bawah Tanah.

(Sumber: Dokumentasi Pribadi)

Pada penelitian ini, contoh kasus penggunaan ruang bawah tanah untuk bangunan gedung yaitu Rumah Asrama/ Kost di Jalan Cisitu Lama XI dan di Jalan Cipaku Permai, menunjukan bahwa individu pemegang hak atas tanah, yaitu hak milik, yang menggunakan ruang bawah tanah jelas diperbolehkan dengan berlandaskan pada ketentuan yang tercantum dalam Pasal 4 Ayat (2) UUPA. Namun pasal tersebut belum cukup memberikan arahan dan batasan dalam penggunaan ruang bawah tanah.

UUPA tidak mengatur secara tegas mengenai penggunaan atau pemanfaatan ruang bawah tanah (tubuh bumi) untuk keperluan pembangunan gedung. Namun demikian tidak berarti bahwa Negara tidak memiliki dasar atau wewenang untuk memberikannya atau bahkan

8 Ires Amanda Putri, Op. Cit., 2013, hlm. 7.

9 Staf Dinas Tata Ruang dan Cipta Karya Kota Bandung.

${ }^{10}$ Hasil wawancara Penulis dengan Bapak Syaiful Iman, Staf Dinas Tata Ruang dan Cipta Karya Kota Bandung. Hari Rabu, 8 Maret 2017, di Kantor Dinas Tata Ruang dan Cipta Karya Kota Bandung. 
menutup kemungkinan untuk melakukan pembangunan gedung di bawah tanah. Jika dilihat kembali dalam Pasal 2 Ayat (2) UUPA, khususnya pada huruf b yang dipakai sebagai dasar dan sekaligus sebagai sumber pengaturan dari Pasal 4 Ayat (1) dan (3) serta Pasal 8 UUPA, di dalam pasal tersebut disebutkan kata "bumi" sebagai salah satu objek pengaturannya. ${ }^{11}$ Pengertian Bumi yang terdapat pada ketentuan Pasal 1 angka 4 UUPA yang menyatakan bahwa:

"Dalam pengertian bumi, selain permukaan bumi, termasuk pula tubuh bumi di bawahnya serta yang berada di bawah air"

Pasal 1 angka 4 dan Pasal 2 Ayat (2) huruf $\mathrm{b}$ tidak secara limitatif merinci atau menyebutkan peruntukan dan penggunaan tubuh bumi. Dengan demikian dapat diartikan bahwa peruntukan dan penggunaan tubuh bumi tidak hanya untuk pengambilan kekayaan alam yang terkandung di dalamnya, tetapi juga dimungkinkan untuk kepentingan lain, termasuk penggunaan peruntukan pembangunan gedung. ${ }^{12}$

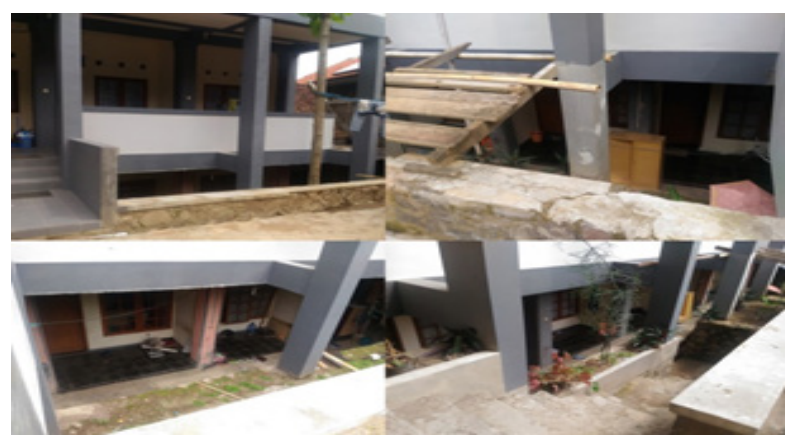

Gambar 1.2 Tampak Depan Bagian Bangunan Gedung yang Berada di Bawah Tanah (Cut and Fill)

(Sumber: Dokumentasi Pribadi)

\footnotetext{
${ }^{11}$ Ires Amanda Putri, Op. Cit., 2013, hlm. 16.

${ }^{12}$ Ibid., hlm. 16-17.

${ }^{13}$ A.M. Yunus Wahid, Loc.Cit.
}

Sementara itu, penggunaan ruang bawah tanah dengan cara 'cut and fill' seperti pada contoh kasus Rumah Kost di Jalan Cisitu Lama XI, sudah menyalahi ketentuan Pasal 1 angka 4 dan Pasal 13 Ayat (2) PP Penatagunaan Tanah yang menyebutkan larangan untuk melakukan 'cut and fill'. 'Cut' dalam konteks ini dapat bermakna menggali, menggusur atau memotong topografi tertentu dan semacamnya. Adapun 'fill' dapat bermakna menimbun, dan semacamnya. ${ }^{13} \mathrm{Di}$ sini terlihat bahwa kurangnya pengawasan dari pihak pemerintah dan tidak adanya penerapan sanksi atas larangan yang dilanggar tersebut.

Kemudian, penggunaan ruang bawah tanah yang lain terjadi di Jakarta untuk MRT, dan Karebosi Link di Makassar. Berdasarkan pada Peraturan Daerah Provinsi DKI Jakarta Nomor 3 Tahun 2008 tentang Pembentukan Badan Usaha Milik Daerah (BUMD) Perseroan Terbatas (PT) MRT Jakarta (sebagaimana diubah dengan Peraturan Daerah Nomor 7 Tahun 2013 tentang Perubahan Atas Peraturan Daerah Nomor 3 Tahun 2008 Tentang Pembentukan Badan Usaha Milik Daerah (BUMD) Perseroan Terbatas (PT) MRT Jakarta) dan Peraturan Daerah Nomor 4 Tahun 2008 Tentang Penyertaan Modal Daerah Pada Perseroan Terbatas (PT) MRT Jakarta (sebagaimana diubah dengan Peraturan Daerah Nomor 8 Tahun 2013 tentang Perubahan Atas Peraturan Daerah Nomor 4 Tahun 2008 tentang Penyertaan Modal Daerah Pada Perseroan Terbatas (PT) MRT Jakarta), Pemda DKI Jakarta melimpahkan wewenangnya kepada PT MRT untuk membangun transportasi MRT yang menggunakan ruang bawah tanah. Begitu pula dengan yang terjadi di Makassar. Pemerintah Kota Makassar memiliki hak 
menguasai Negara dimana hak tersebut bersumber dari hak bangsa Indonesia atas tanah yang memiliki unsur publik, dalam hal ini adalah Lapangan Karebosi. Lebih spesifik, hak yang dimiliki Pemerintah Kota Makassar terhadap tanah Lapangan Karebosi adalah Hak Pengelolaah Lahan. ${ }^{14}$ Hak pengelolaan lahan tersebut dilimpahkan kepada PT Tosan Permai Lestari, yang dalam pelaksanaannya PT Tosan Permai Lestari membangun pusat perbelanjaan di bawah tanah Lapangan Karebosi, yang kemudian dikenal dengan Karebosi Link.

Dengan berlandaskan pada Pasal 2 Ayat (2) UUPA yang menjelaskan tentang hak menguasai dari Negara yang memiliki wewenang salah satunya untuk mengatur dan menyelenggarakan peruntukan, penggunaan, persediaan dan pemeliharaan bumi, air, dan ruang angkasa, pembangunan MRT Jakarta dan Karebosi Link yang menggunakan ruang bawah tanah tersebut diperbolehkan dengan tetap memperhatikan aspek-aspek lain khususnya aspek perizinan yang terkait pembangunan bangunan gedung dan penggunaan ruang bawah tanah, yaitu Izin Pemanfaatan Ruang yang harus disesuaikan dengan RTRW dan harus dipenuhi sebelum melaksanakan pemanfaatan ruang (bawah tanah) yang dapat berupa Izin Prinsip, Izin Lokasi, Izin Penggunaan Pemanfaatan Tanah, Izin Mendirikan Bangunan, dan izin lain berdasarkan ketentuan peraturan perundangundangan.

UU Bangunan Gedung beserta PP Peraturan Pelaksana UU Bangunan Gedung telah menentukan adanya keberadaan bangunan gedung di ruang bawah tanah. Dapat dilihat dari pengertian bangunan gedung yang menyebutkan bahwa bangunan gedung adalah wujud fisik hasil kerja konstruksi yang menyatu dengan tempat kedudukannya sebagian atau seluruhnya berada di atas atau di bawah tanah. Hal ini berarti bahwa selain bangunan yang berada di atas permukaan bumi, ada pula bangunan yang berada di bawah permukaan bumi. ${ }^{15}$

Pembangunan gedung, baik yang berada di atas maupun yang ada di ruang bawah tanah (tubuh bumi), harus memenuhi persyaratan yang bersifat kumulatif seperti syarat administratif yang di dalamnya termasuk menyangkut hak atas tanah dan aspek perizinan. Terhadap hak atas tanahnya, sebelum pendirian bangunan gedung harus dipastikan terlebih dahulu hak atas tanahnya, baik yang menyangkut macam atau jenis haknya, juga subjek serta kepastian luas dan batas-batas tanahnya. Sesuai dengan pengaturan Pasal 11 Ayat (1) Peraturan Pemerintah Republik Indonesia Nomor 36 Tahun 2005 tentang Bangunan Gedung yang berbunyi:

"Setiap bangunan gedung harus didirikan pada tanah yang status kepemilikannya jelas, baik milik sendiri maupun milik pihak lain".

Demikian pula jika bangunan tersebut dibangun atau didirikan di bawah permukaan bumi (tubuh bumi), tentu juga diperlukan persyaratan perizinan pembangunan seperti halnya pembangunan gedung yang berada di atas tanah, yaitu ada hak secara hukum memberi wewenang untuk mendirikan, memiliki dan menggunakan ruang bawah tanah. $^{16}$ Namun permasalahan muncul ketika fungsi dari bangunan gedung yang

\footnotetext{
${ }^{14}$ Ismail Alrip, Farida Patittingi, Faisal Abdullah, Op. Cit., hlm. 6-7.

${ }^{15}$ Ires Amanda Putri, Op. Cit., 2013, hlm. 15.

${ }^{16}$ Ibid., hlm. 14-15.
} 
diperbolehkan didirikan di ruang bawah tanah tidak diperhatikan oleh individu.

Pasal 6 Perda Kota Bandung Tetang Bangunan Gedung membedakan antara bangunan gedung fungsi hunian yang mempunyai fungsi utama sebagai tempat tinggal, yaitu terdapat dalam ketentuan Pasal 6 Ayat (1) yang menyebutkan:

“Bangunan gedung fungsi hunian adalah bangunan yang mempunyai fungsi utama sebagai tempat tinggal manusia yang meliputi rumah tinggal tunggal, rumah tinggal deret, rumah tinggal susun, apartemen dan rumah tinggal sementara."

dengan bangunan gedung fungsi usaha yang termasuk di dalamnya bangunan gedung perhotelan, salah satunya rumah kost, tercantum dalam Pasal 6 Ayat (3), yang menyebutkan:

"Bangunan gedung fungsi usaha adalah bangunan gedung yang mempunyai fungsi utama sebagai tempat melakukan kegiatan usaha, yang dibedakan atas fungsi-fungsi:

a. bangunan gedung perkantoran: perkantoran Badan Usaha Milik Daerah/Badan Usaha Milik Negara, perkantoran swasta, perkantoran niaga, dan sejenisnya;

b. bangunan gedung perdagangan: pasar, pertokoan, pusat perbelanjaan, mall, dan sejenisnya;

c. bangunan gedung perindustrian: industri kecil, industri sedang, industri besar/berat, dan sejenisnya;

d. bangunan gedung perhotelan: hotel, motel, hostel, penginapan, kondotel, rumah kost dan sejenisnya;..."
Dengan adanya perbedaan fungsi bangunan gedung tersebut tentu juga terdapat perbedaan alam persyaratan permohonan Izin Mendirikan Bangunan gedung yang harus dipenuhi. Bangunan gedung yang termasuk kategori rumah tinggal harus memenuhi syarat IMB yang tercantum dalam Pasal 10 Ayat (2) Peraturan Daerah Kotamadya Daerah Tingkat II Bandung Nomor 14 Tahun 1998 tentang Bangunan di Wilayah Kotamadya Daerah Tingkat II Bandung, sedangkan, bangunan gedung yang bukan merupakan bangunan rumah tinggal, salah satunya gedung bertingkat, harus memenuhi syarat yang tercantum dalam Pasal 10 Ayat (3) Peraturan Daerah Kotamadya Daerah Tingkat II Bandung Nomor 14 Tahun 1998 tentang Bangunan di Wilayah Kotamadya Daerah Tingkat II Bandung. Perbedaan syarat IMB bangunan gedung rumah tinggal dengan syarat IMB bangunan gedung non rumah tinggal yakni mengenai hasil penelitian tanah untuk bangunan besar dan/atau terletak di daerah yang struktur rawan bertingkat sebanyak 3 (tiga) set. Diperlukannya syarat tersebut tidak lain adalah untuk tetap menjaga keamanan, keselamatan, keseimbangan, dan keserasian bangunan gedung dengan lingkungannya.

Walaupun terdapat perbedaan fungsi antara bangunan gedung rumah tinggal dengan rumah kost, setelah Penulis melakukan penelitian di Dinas Penanaman Modal dan Pelayanan Terpadu Satu Pintu, Kota Bandung, menurut Bapak Yose ${ }^{17}$ dalam hal pengajuan permohonan IMB tidak dibedakan antara fungsi rumah tinggal dengan rumah kost. Terlihat bahwa terdapat inkonsistensi dalam penerapan persyaratan permohonan IMB berdasarkan fungsi bangunan gedung, karena rumah kost sebagaimana ketentuan

${ }^{17}$ Staf Dinas Penanaman Modal dan Pelayanan Terpadu Satu Pintu Kota Bandung. 
dalam Pasal 6 Ayat (3) Perda Kota Bandung tentang Bangunan Gedung, digolongkan ke dalam bangunan gedung fungsi usaha, yaitu bangunan gedung perhotelan, yang menurut Penulis, fungsi tersebut dapat disamakan dengan bangunan gedung non rumah tinggal. Namun Penulis berpendapat, bahwa bangunan gedung non rumah tinggal yang wajib memenuhi persyaratan IMB sebagaimana Pasal 10 Ayat (3) Peraturan Daerah Kotamadya Daerah Tingkat II Bandung Nomor 14 Tahun 1998 tentang Bangunan di Wilayah Kotamadya Daerah Tingkat II Bandung adalah bangunan gedung yang memiliki tingkat kerawanan/bahaya yang tinggi dalam pendirian bangunan tersebut.

Kemudian dalam Pasal 6 Ayat (6) Perda Kota Bandung tentang Bangunan Gedung terdapat ketentuan yang menyebutkan bahwa:

"Satu bangunan gedung dapat memiliki lebih dari satu fungsi, sepanjang sesuai dengan peruntukan lahan."

Ketentuan dalam Pasal 6 Ayat (6) tersebut menjelaskan bahwa diperbolehkan jika suatu bangunan memiliki fungsi ganda, seperti pada contoh kasus Rumah Asrama/Kost di Jalan Cisitu Lama XI dan di Jalan Cipaku Permai, Kota Bandung, yang merupakan rumah tinggal sekaligus rumah kost.

Penggunaan ruang bawah tanah untuk bangunan gedung yang diatur dalam Perda Kota Bandung tentang Bangunan Gedung hanya mengenai pembangunan bangunan gedung di bawah tanah yang melintasi sarana dan prasarana jaringan kota, dan mengenai penggunaan ruang bawah tanah untuk basement.
IMB tidak menyatakan kepemilikan daripada bangunan gedung tersebut, hanya menyatakan legalitas bangunan. Apakah bangunan sesuai dengan rencana kota atau tidak. Jika perencanaan pembangunan gedung tersebut sesuai dengan rencana kota, izin akan dikeluar oleh pihak yang berwenang. Pada pelaksanaannya, banyak bangunan gedung yang memiliki IMB, namun pendirian bangunan gedung tidak sesuai dengan keterangan yang terdapat dalam IMB. Hal tersebut menunjukan bahwa terdapat penyelewengan penggunaan izin yang sudah diterbitkan. Izin yang terbit dengan kondisi di lapangan berbeda. ${ }^{18}$

Pada umumnya ketika individu mendirikan bangunan gedung di ruang bawah tanah, selain untuk pondasi bangunan gedung yang berada di atas tanah, bangunan gedung tersebut dijadikan basement untuk lahan parkir atau gudang tempat penyimpanan barang. Penggunaan tersebut diperbolehkan dan kemungkinan besar IMB akan dikeluarkan oleh pihak yang berwenang dengan syarat-syarat yang sudah ditentukan. Namun ketika pendirian bangunan gedung di ruang bawah tanah tersebut dijadikan kamar kost, dapat dipastikan izin tidak akan dikeluarkan. Apabila yang individu bersangkutan memiliki izin, dapat dipastikan bahwa izin yang keluar tidak sesuai dengan pembangunan yang dilaksanakan. Jika hal tersebut terjadi, maka telah terjadi adanya suatu penyalahgunaan izin oleh pemegang izin, dan kurangnya pengawasan dari pihak pemerintah sehingga dapat menyebabkan adanya penyalahgunaan izin. ${ }^{19}$

Pemegang hak atas tanah berhak memanfaatkanruangdibawahtanah, termasuk

\footnotetext{
${ }^{18}$ Hasil wawancara Penulis dengan Bapak Syaiful Iman, Staf Dinas Tata Ruang dan Cipta Karya Kota Bandung. Hari Rabu, 8 Maret 2017, di Kantor Dinas Tata Ruang dan Cipta Karya Kota Bandung.

${ }^{19} \mathrm{Ibid}$.
} 
salah satunya untuk membangun bangunan gedung. Setelah melakukan penelitian, Penulis menyimpulkan bahwa penggunaan ruang bawah tanah untuk bangunan gedung diperbolehkan selama sesuai dengan hak yang melekat pada bidang tanah yang digunakan dengan memperhatikan aspek perizinan yang ada, walaupun dalam sertipikat hak atas tanah belum mendukung penggunaan ruang bawah tanah. Bangunan gedung yang berada di ruang bawah tanah dikatakan legal apabila memiliki Izin Mendirikan Bangunan (IMB), dan pendirian bangunan tersebut sesuai dengan IMB yang telah dikeluarkan oleh pihak yang berwenang. Namun, tidak untuk bangunan gedung yang berfungsi sebagai kamar, karena sesuai Perda Kota Bandung tentang Bangunan Gedung, bangunan yang diperbolehkan berada di ruang bawah tanah hanyalah untuk pembangunan bangunan gedung di bawah tanah yang melintasi sarana dan prasarana jaringan kota, dan untuk basement.

\section{Akibat Hukum Atas Penggunaan Ruang di Bawah Tanah untuk Bangunan Gedung Ditinjau dari Peraturan Perundang- Undangan Terkait yang Berlaku}

Suatu perbuatan subjek hukum (manusia Sdan badan hukum) merupakan perbuatan hukum kalau perbuatan itu oleh hukum diberi akibat (mempunyai akibat hukum) dan akibat itu dikehendaki oleh yang bertindak. ${ }^{20}$ Contohnya ialah individu yang mendirikan bangunan gedung di ruang bawah tanah.

Dari adanya penggunaan ruang bawah tanah untuk bangunan gedung oleh individu sebagai subjek hukum, timbullah hak dan kewajiban bagi individu yang melakukan perbuatan hukum tersebut. Individu tersebut, yaitu berhak untuk menggunakan dan memanfaatkan tanah yang dimilikinya, dengan bukti sertipikat hak milik, sekedar diperlukan untuk kepentingan yang langsung berhubungan dengan penggunaan tanah (Pasal 4 Ayat (2) UUPA). Selain timbul hak bagi individu tersebut, timbul pula kewajiban yang harus diperhatikan, yaitu individu sebagai pemegang hak atas tanah wajib menggunakan dan dapat memanfaatkan tanah sesuai Rencana Tata Ruang Wilayah, serta memelihara tanah dan mencegah kerusakan tanah (Pasal 8 PP Penatagunaan Tanah).

Kegiatan pendirian bangunan gedung wajib mengikuti persyaratan untuk dapat memperoleh IMB. Individu yang akan mendirikan bangunan gedung harus memenuhi beberapa persyaratan yang telah ditentukan dalam peraturan perundangundangan. Untuk wilayah Kota Bandung, dibedakan antara persyaratan IMB bangunan gedung rumah tinggal dengan bangunan gedung bukan rumah tinggal yaitu tercantum dalam Pasal 10 Ayat (2) dan Ayat (3) Peraturan Daerah Kotamadya Daerah Tingkat II Bandung Nomor 14 Tahun 1998 tentang Bangunan di Wilayah Kotamadya Daerah Tingkat II Bandung.

Pendirian bangunan gedung sangat berkaitan erat dengan tanah, maka dari itu dalam persyaratan memperoleh IMB disertakan pula bukti kepemilikan tanah. Begitu pula jika bangunan gedung yang akan didirikan berada di ruang bawah tanah. Bukti kepemilikan hak atas tanah, yaitu berupa sertipikat tanah, perlu disertakan dalam pengajuan permohonan IMB. Jika ketika akan mendirikan bangunan gedung ternyata diketahui bahwa peruntukan tanah sebagai tanah pertanian, maka individu wajib melakukan perubahan atas penggunaan

${ }^{20}$ C.S.T. Kansil, Pengantar Ilmu Hukum dan Tata Hukum Indonesia, Balai Pustaka, Jakarta, 1986, hlm. 121. 
tanah dari tanah pertanian menjadi tanah nonpertanian melalui izin perubahan penggunaan tanah, sebelum mengajukan permohonan IMB. Perubahan penggunaan tanah tersebut harus disesuaikan dengan RTRW. Apabila tidak sesuai dengan RTRW, BPN wajib menolak pengajuan izin perubahan penggunaan tanah, dan IMB tidak dapat dikeluarkan. ${ }^{21}$

Pada penggunaan ruang bawah tanah untuk bangunan gedung rumah asrama/ kost di Jalan Cisitiu Lama XI dan Jalan Cipaku Permai, kepemilikan bangunan yang berada di bawah tanah tersebut tidak terpisah dengan kepemilikan bangunan yang berada di permukaan tanah karena individu pemegang hak milik atas tanah juga merupakan individu yang menggunakan dan mendirikan bangunan di ruang bawah tanah. Walaupun di Indonesia menganut asas pemisahan horizontal, namun asas tersebut tidak selalu memisahkan kepemilikan antara bangunan gedung yang berada di permukaan tanah dengan bangunan gedung yang berada di ruang bawah tanah. Sebagai pemegang hak milik atas tanah, seorang individu berhak untuk menggunakan tanahnya, termasuk dengan membangun bangunan gedung di ruang bawah tanah selama tanah tersebut dilekati hak milk atas tanah individu tersebut. Dalam memanfaatkan hak milik atas tanah, hingga saat ini belum ada batasan lain sejauh mana seorang individu dapat menggunakan dan memanfaatkan ruang di bawah tanah yang dilekati hak milik atas tanah baginya, selain sekadar diperlukan untuk kepentingan yang langsung berhubungan dengan penggunaan tanah itu. Namun, apabila terdapat pembatasan dalam penggunaan ruang di bawah tanah yang dilekati hak milik atas tanah pada permukaan tanahnya, maka akan muncul suatu konsekuensi hukum yang harus ditaati berbagai pihak, mulai dari individu, badan hukum, hingga pemerintah.

Selain berkaitan dengan bukti kepemilikan tanah, IMB juga berkaitan dengan Rencana Tata Ruang Wilayah (RTRW). Dalam Pasal 4 Ayat (3) Permen PUPR Nomor 05/Prt/M/2016, bangunan gedung yang didirikan disesuaikan dengan ketentuan dalan RTRW Nasional, RTRW Provinsi, RTRW Kabupaten/Kota, RDTR/ Penetapan Zonasi Kabupaten/Kota, dan/ atau RTBL. Pendirian bangunan gedung rumah asrama/kost di Jalan Cisitu Lama XI dan Jalan Cipaku Permai, menurut Penulis sudah sesuai dengan RTRW dan RDTR Kota Bandung. Rumah asrama/kost di Jalan Cisitu Lama XI yang termasuk ke dalam Blok Dago Kecamatan Coblong tergolong ke dalam zona budidaya yaitu zona perumahan kepadatan tinggi, sedangkan rumah asrama/ kost di Jalan Cipaku Permai termasuk ke dalam Blok Ledeng Kecamatan Cidadap yang tergolong ke dalam zona budidaya yaitu zona perumahan kepadatan sedang. Permohonan IMB dilakukan dengan berdasarkan pada Izin Penggunaan Pemanfaatan Tanah, yang digolongkan ke dalam Izin Pemanfaatan Ruang. Setiap kegiatan yang memanfaatkan ruang, termasuk ruang bawah tanah, harus memiliki Izin Pemanfaatan Ruang22, yang diberikan untukmenjamin pemanfaatan ruang sesuai dengan rencana tata ruang, peraturan zonasi, dan standar pelayanan minimal bidang penataan ruang, mencegah dampak negatif pemanfaatan ruang, dan melindungi kepentingan umum dan masyarakat luas.

\footnotetext{
${ }^{21}$ Hasil wawancara Penulis dengan Bapak Dr. Maret Priyanta, S.H., M.H., Dosen Fakultas Hukum Universitas Padjadjaran, Hari Jum'at, 2 Juni 2017, di Fakultas Hukum Universitas Padjadjaran.

${ }^{22}$ Hasil wawancara Penulis dengan Bapak Syaiful Iman, Staf Dinas Tata Ruang dan Cipta Karya Kota Bandung. Hari Rabu, 8 Maret 2017, di Kantor Dinas Tata Ruang dan Cipta Karya Kota Bandung.
} 
Selain menimbulkan hak dan kewajiban bagi pengguna ruang bawah tanah untuk bangunan gedung, juga akan menimbulkan sanksi apabila terdapat ketidaksesuaian antara pelaksanaan dengan peraturan yang berlaku, salah satunya sanksi administratif bagi setiap orang yang melakukan pelanggaran di bidang penataan ruang, sebagaimana disebutkan dalam Pasal 182 Ayat (1) Peraturan Pemerintah Penyelenggaraan Penataan Ruang, yang dapat berupa ${ }^{23}$ :
"a. peringatan tertulis;
b. penghentian sementara kegiatan;
c. penghentian sementara pelayanan umum;
d. penutupan lokasi;
e. pencabutan izin;
f. pembatalan izin;
g. pembongkaran bangunan;
h. pemulihan fungsi ruang; dan/atau
i. denda administratif."

Selain pelanggaran dalam bidang penataan ruang, juga terkait pelanggaran pada masa konstruksi bangunan gedung yang tidak sesuai dengan dokumen IMB dikenakan sanksi administratif berupa pembekuan dan pencabutan IMB sesuai ketentuan peraturan perundang-undangan (Pasal 48 Ayat (1) Permen PUPR No. 05/Prt/M/2016).

Bangunan gedung ruang bawah tanah yang berada di Jalan Cisitu Lama XI dan Jalan Cipaku Permai, yang dinilai sudah melanggar aturan, tentu menimbulkan akibat hukum yaitu berupa pengenaan sanksi sebagaimana ketentuan dalam peraturan perundang-undangan terkait yang berlaku, diantaranya adalah ketentuan dalam Pasal
45 UU Bangunan Gedung, Pasal 182 Ayat (1) Peraturan Pemerintah Penyelenggaraan Penataan Ruang, dan Pasal 48 Ayat (1) Permen PUPR No. 05/Prt/M/2016. Berbagai aspek harus diperhatikan yang merupakan kewajiban setiap orang perorangan atau badan hukum dalam menggunakan tanah, khususnya ruang bawah tanah untuk bangunan gedung, mulai dari memperhatikan hak atas tanah yang melekat pada tanah yang dimiliki, penataan ruang, perizinan, hingga persyaratan pendirian bangunan gedung.

Melihat semakin maraknya penggunaan ruang bawah tanah di kota-kota besar seperti Kota Bandung, Jakarta, dan Makassar, Penulis berpendapat bahwa perlu adanya suatu pengaturan khusus setara dengan undang-undang yang mengatur mengenai ruang bawah tanah, dan menjelaskan peruntukan penggunaan ruang bawah tanah dengan menyelaraskan aspek-aspek lainnya yang terkait seperti aspek penataan ruang, dan perizinan, agar dalam pelaksanaan penggunaan ruang bawah tanah memiliki landasan hukum yang kuat. Selain itu, perlu adanya pengawasan yang ketat dari pemerintah, dan kesadaran dari masyarakat untuk dapat meminimalisir terjadinya pelanggaran dan penyalahgunaan izin yang diberikan, sehingga ruang bawah tanah dapat dipergunakan secara maksimal dengan tetap menjaga keseimbangan lingkungan.

\section{PENUTUP}

Rerdasarkan hasil pembahasan yang D dikemukakan pada bab-bab sebelumnya, maka Penulis menarik kesimpulan bahwa bangunan gedung yang berada di ruang bawah tanah dikatakan legal apabila memiliki Izin Mendirikan Bangunan gedung (IMB), dan

${ }^{23}$ Pasal 182 Ayat (3) Peraturan Pemerintah Nomor 15 Tahun 2010 tentang Penyelenggaraan Penataan Ruang. 
pendirian bangunan gedung tersebut sesuai dengan IMB yang telah dikeluarkan oleh yang berwenang sebagaimana ketentuan mengenai IMB yang terdapat dalam Permen PUPR IMB Gedung dan peraturan perundang-undangan lain terkait IMB. Selain itu, penggunaan ruang bawah tanah untuk bangunan gedung yang melanggar aturan menimbulkan akibat hukum berupa pengenaan sanksi sebagaimana ketentuan dalam peraturan perundang-undangan terkait yang berlaku, diantaranya ialah ketentuan dalam Pasal 45 UU Bangunan Gedung, Pasal 182 Ayat (1) PP Penyelenggaraan Penataan Ruang, dan Pasal 48 Ayat (1) Permen PUPR IMB Gedung.

\section{DAFTAR PUSTAKA}

\section{Buku}

Harsono, B., Hukum Agraria Indonesia Sejarah Pembentukan Undang-Undang Pokok Agraria, Isi dan Pelaksanaannya. Djambatan, Jakarta, 2008;

Ismail Alrip, F. P. F. A., n.d. Pengaturan Pemanfaatan Ruang Bawah Tanah. Makassar: Fakultas Hukum Universitas Hasanuddin.

Kansil, C., Pengantar Ilmu Hukum dan Tata Hukum Indonesia. Balai Pustaka, Jakarta, 1986.

Limbong, B., Politik Pertanahan. Margaretha Pustaka, Jakarta, 2014.

Putri, I. A., Jurnal Singkat: Asas Pemisahan Horizontal dalam Pemanfaatan Ruang Bawah Tanah Berdasarkan Hukum Pertanahan Indonesia (Tinjauan Yuridis terhadap Putusan Mahkamah Agung Nomor $740 \mathrm{~K} / \mathrm{Pdt} / 2009$, Nomor 292 PK/Pdt/2009. Nomor 2030 K/Pdt/2003. Fakultas Hukum Universitas Indonesia, Depok, 2013.

Sumardjono, M. S., Tanah dalam Perspektif Hak Ekonomi Sosial dan Budaya. Jakarta: Penerbit Buku Kompas.
Wahid, A. Y., 2014. Pengantar Hukum Tata Ruang, Kencana, Jakarta, 2008.

\section{Peraturan Perundang-Undangan}

Undang-Undang Dasar Negara Republik Indonesia Tahun 1945 hasil amandemen ke-empat;

Undang-Undang Nomor 5 Tahun 1960 Tentang Peraturan Dasar Pokok-Pokok Agraria;

Undang-Undang Nomor 28 Tahun 2002 Tentang Bangunan Gedung;

Undang-Undang Nomor 26 Tahun 2007 Tentang Penataan Ruang;

Peraturan Pemerintah Nomor 24 Tahun 1997 Tentang Pendaftaran Tanah;

Peraturan Pemerintah Nomor 16 Tahun 2004 Tentang Penatagunaan Tanah;

Peraturan Pemerintah Nomor 36 Tahun 2005 Tentang Peraturan Pelaksanaan UndangUndang Nomor 28 Tahun 2002 Tentang Bangunan Gedung;

Peraturan Pemerintah Nomor 15 Tahun 2010

Tentang Penyelenggaraan Penataan Ruang;

Peraturan Menteri Pekerjaan Umum Nomor 02/Prt/M/2014 Tentang Pedoman Pemanfaatan Ruang di Dalam Bumi;

Peraturan Menteri Pekerjaan Umum dan Perumahan Rakyat Republik Indonesia Nomor 05/PRT/M/2016 Tentang Izin Mendirikan Bangunan Gedung;

Peraturan Daerah Kotamadya Daerah Tingkat II Bandung Nomor 14 Tahun 1998 Tentang Bangunan di Wilayah Kotamadya Daerah Tingkat II Bandung;

Peraturan Daerah Kota Bandung Nomor 05 Tahun 2010 Tentang Bangunan Gedung. 